\title{
Effect of thyroparathyroidectomy on urinary acidification in diabetic rats
}

F. Zaladek-Gil, M.F. Cavanal,

G. N ascimento-Gomes,

M.C. Silva-Rocha and

M. Nutti-de-Almeida
Departamento de Fisiologia, Escola Paulista de Medicina, Universidade Federal de São Paulo, São Paulo, SP, Brasil

\author{
Correspondence \\ F. Zaladek-Gil \\ Disciplina de Fisiologia Renal e \\ Termometabologia, EPM, UNIFESP \\ Rua Botucatu, 862, 5ㅇadar \\ 04023-900 São Paulo, SP \\ Brasil \\ Fax: + 55-11-570-6567 \\ Research supported by \\ FAPESP and CNPq.
}

Received June 5, 1998

Accepted October 19, 1998

\section{Abstract}

In previous studies we have shown stimulation of renal acid excretion in the proximal tubules of rats with diabetes of short duration, with no important alterations in glomerular hemodynamics; on the other hand, in thyroparathyroidectomized rats (TPTX model), a significant decrease in renal acid excretion, glomerular filtration rate (GFR) and renal plasma flow (RPF) was detected. Since important changes in the parathyroid hormone-vitamin $\mathrm{D}-\mathrm{Ca}$ axis are observed in the diabetic state, the present study was undertaken to investigate the renal repercussions of thyroparathyroidectomy in rats previously made diabetic by streptozotocin $(45 \mathrm{mg} / \mathrm{kg})$. Four to 6 days after the induction of diabetes (DM), a group of rats were thyroparathyroidectomized (DM + TPTX). Renal functional parameters were evaluated by measuring the inulin and sodium para-aminohippurate clearance on the tenth day. The decrease in the GFR and RPF observed in TPTX was not reversed by diabetes since the same alterations were observed in DM + TPTX. Net acid (NA) excretion was unchanged in DM $(6.19 \pm 0.54)$, decreased in TPTX $(3.76 \pm 0.25)$ and returned to normal levels in DM + TPTX $(5.54 \pm 0.72)$ when compared to the control group $(6.34 \pm 0.14$ $\left.\mu \mathrm{mol} \mathrm{min}{ }^{-1} \mathrm{~kg}^{-1}\right)$. The results suggest that PTH plays an important vasodilator role regarding glomerular hemodynamics, since in its absence the impairment in GFR and RPF was not reversed by the diabetic state. However, with respect to acid excretion, the presence of diabetes was able to overcome the negative stimulus represented by TPTX.

\section{Introduction}

The mechanism of urinary acidification has been shown to be altered in several diseases, as well as in experimental models. In a previous study, we showed that an increase in the rate of proximal tubular acidification was demonstrable in rats made diabetic (DM) by intraperitoneal administration
Key words - Diabetes

- Thyroparathyroidectomy

- Renal function

- Acid excretion

..................... 
metabolic pathways which include stimulation of proximal tubular $\mathrm{Na}^{+}$reabsorption (10), renal tubular activity of $\mathrm{Na}^{+}-\mathrm{K}^{+}$-ATPase $(11,12)$ and protein kinase activity $(13,14)$. On the other hand, hyperparathyroidism has been associated with both metabolic acidosis and alkalosis. Pollock et al. (15) showed that parathyroid hormone (PTH) inhibits $\mathrm{Na}^{+}$ and volume reabsorption in the proximal tubule, which could lead to metabolic acidosis, while Bichara et al. (16) proposed that hyperparathyroidism could cause metabolic alkalosis of renal origin since the hormone stimulated the tubular excretion of ammonium and titratable acidity.

Since disturbances in PTH and $\mathrm{Ca}^{2+}$ metabolism are frequently reported in the diabetic state $(17,18)$ and that secondary hyperparathyroidism which accompanies chronic renal failure is associated with derangements in insulin release (19), the present study was designed to focus on the effects of both DM and TPTX on renal functional parameters, with special emphasis on urinary acidification.

\section{Material and Methods}

Male Wistar rats weighing 200 to $300 \mathrm{~g}$ were obtained from Escola Paulista de Medicina, São Paulo, Brazil. They received a rat pellet diet and water ad libitum until the time of the experiments. Diabetes was induced by intraperitoneal (ip) injection of 45 $\mathrm{mg} / \mathrm{kg}$ streptozotocin (STZ) 10 days before the experiments, and prepared in citrate buffer, $\mathrm{pH}$ 4.0. The induction of diabetes was confirmed by measuring glycemia 5-6 days after drug administration. The rats that presented glycemia below $280 \mathrm{mg} \%$ were not used in the study. Thyroparathyroidectomy was then performed under ether anesthesia and was considered successful only when total plasma calcium concentration fell by $1.75 \mathrm{mg} / \mathrm{dl}$ or more from preoperative levels, $24 \mathrm{~h}$ after surgery. The following groups were studied: sham-operated control group (C) $(\mathrm{N}=9)$, DM rats $(\mathrm{N}=9)$, TPTX rats $(\mathrm{N}=9)$ and $\mathrm{DM}+\mathrm{TPTX}(\mathrm{N}=9)$.

Thyroxin, $1 \mu \mathrm{g} / 100 \mathrm{~g}$ body weight, was given by subcutaneous injection to TPTX rats, every $24 \mathrm{~h}$. This dose has been shown to be necessary to reach euthyroidism (2). At the time of the experiments, the animals were anesthetized with Inactin (Byk-Gulden, Konstanz, Germany), $100 \mathrm{mg} / \mathrm{kg}$ ip, and prepared for clearance measurements. Briefly, the jugular vein, carotid artery and urinary bladder were cannulated for infusion and blood and urine withdrawal, respectively. A tracheotomy was performed.

\section{Clearance measurements}

To evaluate the glomerular filtration rate (GFR) and the renal plasma flow (RPF), after a priming dose of inulin and sodium $\mathrm{p}$ aminohippurate (PAH), $30 \mathrm{mg} / 100 \mathrm{~g}$ and 2 $\mathrm{mg} / \mathrm{rat}$, respectively, the infusion of a sustaining dose of inulin, $0.05 \mathrm{mg} \mathrm{min}^{-1} 100 \mathrm{~g}^{-1}$, and of PAH, $40 \mathrm{mg} / 10 \mathrm{ml}$, in isotonic saline was initiated at a rate of $0.06 \mathrm{ml} / \mathrm{min}$. After a stabilization period of $30 \mathrm{~min}$, four clearance periods of $30 \mathrm{~min}$ were studied. Blood samples were obtained at the midpoint of each clearance period. Urine was collected quantitatively in preweighed containers, and urine volume was determined gravimetrically. Inulin concentration in plasma and urine was measured by the method of Fuehr et al. (20) and PAH concentration in plasma and urine by the method of Smith et al. (21), both adapted for smaller plasma and urine volumes. Urine and plasma $\mathrm{Na}^{+}$and $\mathrm{K}^{+}$concentrations were determined with an $\mathrm{Na}^{+} / \mathrm{K}^{+}$ analyzer, model 248 (Ciba-Corning Diagnostics Ltd., Essex, England). Urine and blood $\mathrm{pH}, \mathrm{pCO}_{2}$ and bicarbonate values were obtained with a Ciba-Corning, model 614 blood gas analyzer. Titratable acidity (TA) in urine was measured by microtitration and ammonium excretion $\left(\mathrm{NH}_{4}^{+}\right)$by the spectrophotometric method of Connerty et al. (22). Net acid (NA) excretion was calculated by 
the formula: $\mathrm{NA}=\mathrm{TA}+\mathrm{NH}_{4}{ }^{+}-\mathrm{C}_{\mathrm{HCO}_{3}}{ }^{-}$ where $\mathrm{C}_{\mathrm{HCO}_{3}}{ }^{-}$is the excreted amount of bicarbonate. Ionized calcium was measured with a calcium-selective electrode, model 9140 (AVL Scientific Corporation, Roswell, NM, USA). Total calcium in plasma and urine specimens was measured by a colorimetric method.

\section{Statistical analysis}

The results are reported as means \pm SEM and were analyzed statistically by analysis of variance followed by the Scheffé test and by the Kruskal-Wallis test followed by Dunn's post-test, when necessary, with the level of significance set at 0.05 .

\section{Results}

Streptozotocin induced an overt diabetic state in the treated rats, as shown by the mean glycemia values obtained for these animals, i.e., $317.50 \pm 13.56$ and $322.8 \pm$ 15.23 for DM and DM + TPTX rats, respectively. These values were significantly higher $(\mathrm{P}<0.001)$ than those of the control and TPTX rats, $86.0 \pm 2.98$ and $88.7 \pm 5.44 \mathrm{mg} / \mathrm{dl}$, respectively. The final body weight of the studied groups was similar.

Table 1 shows the acid-base data for the groups studied. Diabetic rats presented a lower urine $\mathrm{pH}$ than that of the control group, which suggests that acid excretion was stimulated in this condition, probably due to the
Table 1 - Acid-base data of control (C), diabetic (DM), thyroparathyroidectomized (TPTX) and DM + TPTX rats.

Data are reported as means \pm SEM for the number of measurements given within parentheses. Significance level: $* \mathrm{P}<0.05$ vs $\mathrm{C} ; * * \mathrm{P}<0.05$ vs $\mathrm{DM}$; $+\mathrm{P}<0.05$ vs TPTX.

\begin{tabular}{lccl}
\hline Group & Blood pH & Blood $\mathrm{HCO}_{3}(\mathrm{mEq} / \mathrm{l})$ & \multicolumn{1}{c}{ Urine $\mathrm{pH}$} \\
\hline Control (15) & $7.41 \pm 0.01$ & $20.05 \pm 0.70$ & $6.11 \pm 0.06$ \\
DM (24) & $7.38 \pm 0.01$ & $17.8 \pm 0.83$ & $5.88 \pm 0.046^{*}$ \\
TPTX (20) & $7.40 \pm 0.01$ & $16.86 \pm 0.52^{*}$ & $6.20 \pm 0.04^{* *}$ \\
DM + TPTX (22) & $7.35 \pm 0.042$ & $22.09 \pm 0.78^{* *+}$ & $6.18 \pm 0.046^{* *}$
\end{tabular}

acid overload produced by the metabolism of the diabetic rats. In TPTX, although blood $\mathrm{HCO}_{3}{ }^{-}$was decreased, urine $\mathrm{pH}$ was not different from control values, suggesting that a renal compensation mechanism was not triggered.

As shown in Table 2, thyroparathyroidectomy induced a significant decrease in GFR, U/P inulin and in RPF; these alterations were also present in DM + TPTX, suggesting that in this model of acute diabetic state the vasoconstrictor stimulus, i.e., the absence of PTH, was preponderant over glomerular hemodynamics. NA was unchanged in DM when compared to control values, as seen in Table 3. A significant decrease in NA was obtained in TPTX, mainly due to a decrease in titratable acidity; in the DM + TPTX group, NA returned to values not different from those for $\mathrm{C}$ and $\mathrm{DM}$, suggesting that the presence of DM was a more potent stimulus of acid excretion than the inhibition promoted by the absence of PTH.

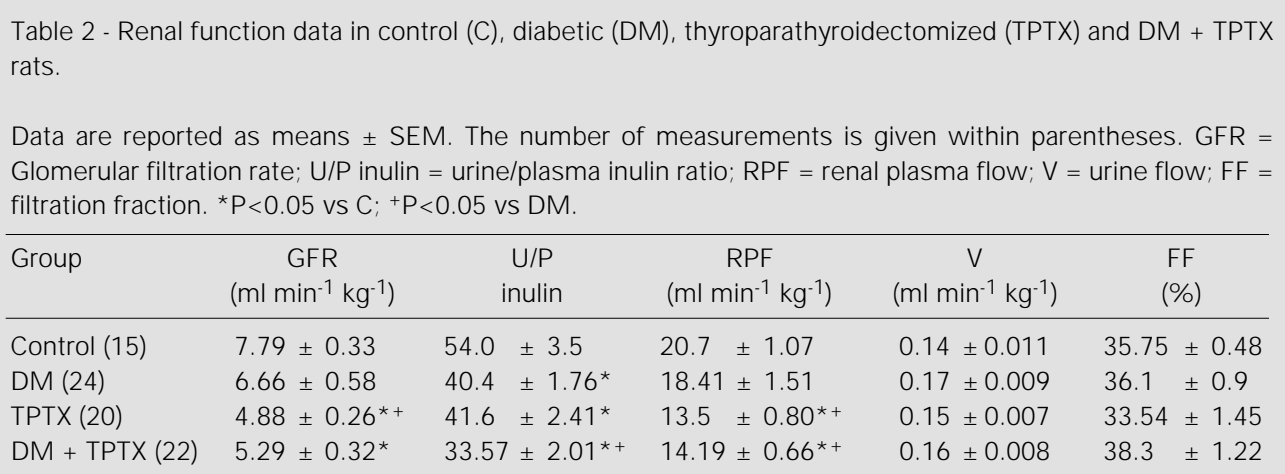




\begin{tabular}{|c|c|c|c|c|}
\hline \multicolumn{5}{|c|}{ 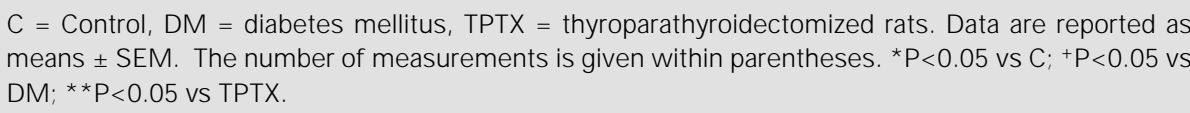 } \\
\hline Group & 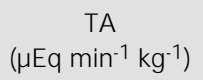 & $\begin{array}{c}\mathrm{NH}_{4}^{+} \\
\left(\mu \mathrm{Eq} \mathrm{\textrm {min } ^ { - 1 }} \mathrm{kg}^{-1}\right)\end{array}$ & $\begin{array}{c}\mathrm{C}_{\mathrm{HCO}_{3}^{-}}^{-} \\
\left(\mu \mathrm{Eq} \mathrm{\textrm {min } ^ { - 1 }} \mathrm{kg}^{-1}\right)\end{array}$ & 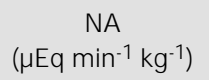 \\
\hline$C(24)$ & $2.41 \pm 0.13$ & $4.1 \pm 0.34$ & $0.12 \pm 0.01$ & $6.34 \pm 0.14$ \\
\hline DM (24) & $2.78 \pm 0.208$ & $3.49 \pm 0.36$ & $0.08 \pm 0.009$ & $6.19 \pm 0.541$ \\
\hline TPTX (19) & $1.48 \pm 0.13^{*+}$ & $2.49 \pm 0.98$ & $0.23 \pm 0.04$ & $3.76 \pm 0.25^{*+}$ \\
\hline $\mathrm{DM}+\mathrm{TPTX}(22)$ & $2.43 \pm 0.18^{* *}$ & $3.32 \pm 0.67$ & $0.28 \pm 0.08$ & $5.54 \pm 0.72^{* *}$ \\
\hline
\end{tabular}

Table 4 - Plasma (ionized and total) calcium and urinary calcium excretion in the groups studied.

$\mathrm{C}=$ Control; $\mathrm{DM}=$ diabetes mellitus; TPTX = thyroparathyroidectomized rats. Data are reported as means \pm SEM. The number of measurements is given within parentheses. $* P<0.05$ vs $C ;+P<0.05$ vs $\mathrm{DM} ; * * \mathrm{P}<0.05$ vs TPTX.

\begin{tabular}{lllll}
\hline Group & $\begin{array}{c}\text { Ionized calcium } \\
(\mathrm{mEq} / \mathrm{l})\end{array}$ & $\begin{array}{c}\text { Total plasma } \\
\text { calcium }(\mathrm{mg} / \mathrm{dl})\end{array}$ & $\begin{array}{c}\text { Excreted amount } \\
\text { of calcium } \\
\left(\mathrm{mg} \mathrm{min}^{-1} \mathrm{~kg}^{-1}\right)\end{array}$ & $\begin{array}{c}\text { Fractional } \\
\text { excretion } \\
(\%)\end{array}$ \\
\hline Control (9) & $1.21 \pm 0.01$ & $8.29 \pm 0.12$ & $0.30 \pm 0.02$ & $0.56 \pm 0.04$ \\
DM (9) & $1.24 \pm 0.01$ & $7.88 \pm 0.45$ & $0.23 \pm 0.054$ & $0.47 \pm 0.106$ \\
TPTX (9) & $0.66 \pm 0.05^{*+}$ & $5.31 \pm 0.66^{*+}$ & $2.10 \pm 0.31^{*+}$ & $1.10 \pm 0.16^{*+}$ \\
DM + TPTX (9) & $0.98 \pm 0.08^{*+* *}$ & $6.42 \pm 0.54^{*}$ & $3.16 \pm 0.21^{*+}$ & $1.24 \pm 0.20^{*+}$ \\
& & & &
\end{tabular}

As seen in Table 4, diabetic rats showed no alterations in $\mathrm{Ca}^{2+}$ metabolism. As expected, TPTX showed a significant decrease in calcemia and an increase in the absolute and relative levels of calcium excretion. Although the presence of diabetes tended to elevate the ionizable $\mathrm{Ca}^{2+}$ in the TPTX group, the rates of calcium excretion remained increased in DM + TPTX, suggesting that diabetes was unable to change the tubular handling of $\mathrm{Ca}^{2+}$ when PTH was absent.

Mean blood sodium and potassium levels and the fractional excretion of these ions are shown in Table 5. The fractional excretion of $\mathrm{Na}^{+}$was significantly increased in TPTX and returned to normal values in DM + TPTX, suggesting that diabetes and thyroparathyroidectomy may have opposite effects concerning $\mathrm{Na}^{+}$reabsorption. Diabetic rats showed an increase in the fractional excretion of $\mathrm{K}^{+}$, an alteration that could be the result of osmotic diuresis and/or intracel- lular acidosis; the same alterations were obtained in the DM + TPTX group.

\section{Discussion}

A number of studies have shown that vitamin D metabolism and tubular responsiveness to PTH are impaired in diabetic rat models $(17,18,23)$. Clinical studies have also shown that, in diabetic patients on hemodialysis, the magnitude of secondary hyperparathyroidism is generally lower than in other dialysis patients (24) and the occurrence of low bone turnover which results in adynamic bone disease is frequent (25). These studies provide strong evidence that the relationship between insulin and the PTH-Ca ${ }^{2+}$ axis is complex and that several membrane transporters may be affected by these hormones.

Diabetes has been shown to be responsible for a number of pathophysiological 


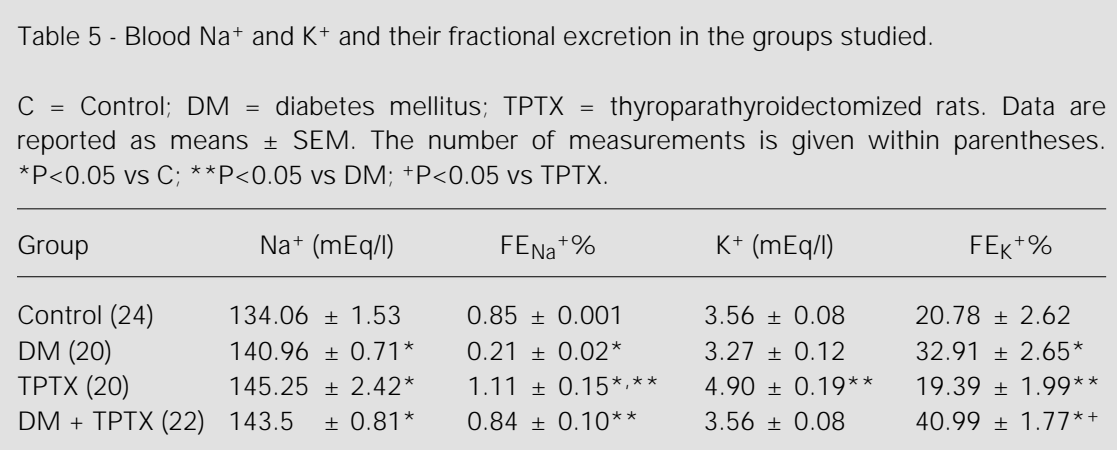

alterations in renal function, including modifications in glomerular hemodynamics (26) and in urinary acidification (1). The hyperfiltrating state, with glomerular capillary hypertension, may be one of the first alterations caused by DM (27); however, in our model diabetes was present for a short period of time, probably insufficient to cause significant changes in GFR and RPF. The decrease in GFR and RPF observed in TPTX confirms the action of $\mathrm{PTH}$ as a renal vasodilator (28) and these changes persisted even in the presence of DM, which theoretically could protect renal arterioles against vasoconstriction, suggesting that, concerning hemodynamic effects, the effect of the absence of PTH is preponderant over DM. These alterations in glomerular hemodynamics were previously shown in TPTX animals receiving or not oral calcium supplementation (2), suggesting that the presence of PTH (and not a normal calcemia) was fundamental to maintain the renal hemodynamics at normal levels.

As shown by Carney and Gillies (29), PTH may act as a partial agonist of arginine vasopressin in the collecting system, which means that in TPTX an impairment in the urine-concentrating ability is not unexpected. This effect, together with the osmotic diuresis of DM, could further decrease the U/P inulin ratio, as observed in the DM + TPTX animals.

Net acid excretion was significantly impaired in TPTX, but when rats were previously made diabetic, NA returned to values observed in intact animals. In order to understand these findings, it is important to discuss the known effects of diabetes mellitus and thyroparathyroidectomy on urinary acidification. In micropuncture and microperfusion experiments it has been demonstrated that proximal tubular $\mathrm{Na}^{+}$reabsorption is increased in diabetes mellitus $(30,31)$ and that the proximal reabsorption rates of bicarbonate are stimulated (1); in the present study, since the urinary flow as well as the final body weight were unchanged, the lower $\mathrm{FE}_{\mathrm{Na}^{+}}$seen in DM reflects an increased tubular reabsorption of $\mathrm{Na}^{+}$rather than a decrease in the extracellular volume status. On the other hand, previous studies from this laboratory (32) have shown that the rates of bicarbonate reabsorption in the proximal tubule of TPTX rats were decreased to the same extent as in a model of intact rats, whose tubules were perfused with a solution containing EGTA, an agent that chelates calcium. Interestingly, when the proximal tubules of TPTX were perfused with a calcium ionophore added to the luminal side, the reabsorption rates returned to normal levels, pointing to an important role of calcium as a mediator of luminal acidification. In the present study, we observed that in the diabetic state renal handling of calcium and total as well as ionizable $\mathrm{Ca}^{2+}$ were within the normal range, which means that in this model of STZ-induced diabetes no significant alterations in calcium metabolism occurred. Moreover, diabetes did not change the renal handling of $\mathrm{Ca}^{2+}$ in rats submitted 
to thyroparathyroidectomy. These findings suggest that, concerning tubular handling of $\mathrm{Ca}^{2+}$, the presence of hyperglycemia probably has no significant role in modulating PTH effects, a conclusion also reached by Wongsurawat and Armbrecht (33). Although these investigators used a model in which the induction of diabetes followed thyroparathyroidectomy (TPTX + DM), they concluded that insulin did not modulate the PTH effects with respect to calcemia and phosphaturia.

An important increase in the $\mathrm{Na}^{+} / \mathrm{H}^{+}$ antiport activity was observed in leukocytes from diabetic animals, which was reversed by incubation with staurosporine, a protein kinase inhibitor, suggesting that protein kinase activity (including PKC) may be higher in diabetic subjects $(13,14,34)$; PKC is also stimulated when PTH binds to the basolateral receptor in renal tubular cells, as shown by Dumlay and Hruska (35). In this way, when both conditions are present, DM + TPTX, an equilibrium between a stimulating (diabetes) and an inhibitory event (parathyroidectomy) would be expected to bring acidification to normal levels. The normal levels of acidification obtained in DM + TPTX could be also explained by taking into account the known effects of both diabetes mellitus and PTH on intracellular calcium levels $\left[\mathrm{Ca}^{2+}\right]$ i. In a recent study, Smogorzewski et al. (36) conclude that when rat cardiac myocytes were incubated in a high glucose medium, an experimental model that simulates the diabetic state, a significant rise in $\left[\mathrm{Ca}^{2+}\right] \mathrm{i}$ was observed, probably mediated by activation of calcium channels and, to a lesser extent, by activation of cAMP-protein kinase A. A significant rise in $\left[\mathrm{Ca}^{2+}\right] \mathrm{i}$ was also observed in rat polymorphonuclear cells incubated with a high glucose medium (36). On the other hand, PTH also causes a rise in $\left[\mathrm{Ca}^{2+}\right] \mathrm{i}$ in many cells, including renal tubular cells $(37,38)$. Thus, a fall in $\left[\mathrm{Ca}^{2+}\right] \mathrm{i}$ could be expected in TPTX. When both conditions are present simultaneously, DM + TPTX, a near normal cytosolic $\mathrm{Ca}^{2+}$ could be present, resulting in an adequate luminal $\mathrm{Na}^{+} / \mathrm{H}^{+}$ antiport.

We have demonstrated that diabetic rats submitted to thyroparathyroidectomy are able to maintain a normal level of acid excretion despite the impaired glomerular function. The results suggest that glomeruli and tubules may react differently to the same hormonal stimulus due to the predominance of different receptors in these renal structures. Our results may also suggest that the reported altered sensitivity of the diabetic nephron to the action of PTH may be regarded as a compensatory mechanism which may prevent an exacerbated response to this hormonal stimulus.

\section{References}

1. Nascimento Gomes G, Zaladek Gil F \& Mello-Aires M (1997). Alterations in renal handling of $\mathrm{H}^{+}$in diabetic rats. Kidney and Blood Pressure Reseach, 20: 251-257.

2. Zaladek-Gil F, Costa-Silva VL, Cavanal MF \& Malnic G (1992). Effects of parathyroid hormone and calcium and their interrelationship on urinary acidification in the rat. Clinical Science, 83: 711-715.

3. Preisig PA \& Alpern RJ (1988). Chronic metabolic acidosis causes an adaptation in the apical membrane $\mathrm{Na} / \mathrm{H}$ antiporter and the basolateral membrane $\mathrm{Na}\left(\mathrm{HCO}_{3}\right)_{3}$ symporter in the rat proximal convoluted tubule. J ournal of Clinical Investigation,
82: 1445-1453.

4. Tsai CJ, Ives HE, Alpern RJ, Yee VJ, Warnock DG \& Rector J r FC (1984). Increased $\mathrm{V}_{\max }$ for $\mathrm{Na} / \mathrm{H}$ antiporter activity in proximal tubule brush border vesicles from rabbits with metabolic acidosis. American J ournal of Physiology, 247: F339-F343.

5. Akiba T, Rocco VK \& Warnock DG (1987). Parallel adaptation of the rabbit renal cortical sodium/proton antiporter and sodium/bicarbonate cotransporter in metabolic acidosis and alkalosis. J ournal of Clinical Investigation, 80: 308-315.

6. Krapf R, Pearce D, Lynch C, Xi XP,
Reudelhuber TL, Pouysségur J \& Rector J r FC (1991). Expression of rat renal $\mathrm{Na} / \mathrm{H}$ antiporter mRNA levels in response to respiratory and metabolic acidosis. J ournal of Clinical Investigation, 87: 747-751.

7. Liu FY \& Cogan MG (1987). Angiotensin II stimulation of hydrogen ion secretion in the rat early proximal convoluted tubule. J ournal of Clinical Investigation, 80: 272275.

8. Halperin ML, Goldstein MB, Richardson RMA \& Stinebaugh BJ (1985). Distal renal tubular acidosis syndromes: A pathophysiological approach. American J ournal of Nephrology, 5: 1-8. 
9. Kamel KS, Briceno LF, Sanchez MI, Brenes L, Yorgin P, Kooh SW, Balfe J W \& Halperin ML (1997). A new classification for renal defects in net acid excretion. American J oumal of Kidney Diseases, 29: 136-146.

10. Pollock CA, Lawrence J R \& Field MJ (1991). Tubular sodium handling and tubuloglomerular feedback in experimental diabetes mellitus. American J ournal of Physiology, 260: F946-F952.

11. Ku DD, Sellers BM \& Meezan E (1986). Development of renal hypertrophy and increased renal $\mathrm{Na}^{+} \mathrm{K}^{+} \mathrm{ATPase}$ in streptozocin-diabetic rats. Endocrinology, 119: 672679.

12. Khadouri C, Barlet-Bas C \& Doucet A (1987). Mechanism of increased tubular $\mathrm{Na}^{+}-\mathrm{K}^{+}-$ATPase during streptozotocin-induced diabetes. Pflügers Archives, European J ournal of Physiology, 409: 296-301.

13. Xia $P$, Inoguchi $T$, Kem TS, Engeman RL, Oates PJ \& King GL (1994). Characterization of the mechanism for the chronic activation of diacyl-glycerol- protein kinase $C$ pathways in diabetes and hypergalactosemia. Diabetes, 43: 1122-1129.

14. Craven PA \& DeRubertis FR (1989). Protein kinase $C$ is activated in glomeruli from streptozotocin diabetic rats. J ournal of Clinical Investigation, 83: 1667-1675.

15. Pollock AS, Warnock DG \& Strewler GJ (1986). Parathyroid hormone inhibition of $\mathrm{Na}-\mathrm{H}$ antiporter in a cultured renal cell line. American J ournal of Physiology, 245: F450-F461.

16. Bichara $M$, Mercier $O$, Paillard $M$ \& Leviel $F$ (1986). Effects of parathyroid hormone on urinary acidification. American J oumal of Physiology, 251: F444-F453.

17. Wongsurawat N, Armbrecht J H \& Siegel NA (1991). Effects of diabetes mellitus on parathyroid hormone-stimulated protein kinase activity, ferrodoxin phosphorylation and renal 1,25-dihydroxyvitamin D production. J ournal of Laboratory and Clinical Medicine, 117: 319-324.

18. J ara A, Bover J \& Felsenfeld AJ (1995). Development of secondary hyperparathyroidism and bone disease in diabetic rats with renal failure. Kidney International, 47: 1746-1751.

19. Akmal $M$, Kasim SE, Soliman AR \&
Massry SG (1990). Excess parathyroid hormone adversely affects lipid metabolism in chronic renal failure. Kidney International, 37: 854-858.

20. Fuehr J, Kaczmarczyk J \& Hrüttgen CD (1955). Eine einfache colorimetrische Methode zur Inulinbestimmung für Nieren-Clearance-Untersuchungen bei Stoffwechsegesunden und Diabetikem. Klinische Wochenschrift, 33: 729-730.

21. Smith HW, Finkelstein N, Aliminosa L, Crawford B \& Graber M (1945). The renal clearances of substituted hippuric acid derivatives and other aromatic acids in dogs and man. J ournal of Clinical Investigation, 24: 388-404.

22. Connerty VA, Angles MD, Briggs $R \&$ Eaton EH (1957). Determination of preformed urinary ammonia (nitrogen) by means of direct nesslerization. American J ournal of Clinical Pathology, 28: 634-638.

23. Wongsurawat N \& Armbrecht J H (1991). Calcitonin stimulates 1,25 dihydroxyvitamin $D$ production in diabetic rat kidney. Metabolism, 40: 22-25.

24. Martinez I, Saracho R, Moina I, Montenegro J \& Llach F (1998). Is there a lesser hyperparathyroidism in diabetic patients with chronic renal failure? Nephrology, Dialysis, Transplantation, 13: 9-11.

25. Sherrard DJ , Hercz G, Pei Y, Maloney NA, Greenwood C, Manuel A, Saiphoo C, Fenton SS \& Segre GV (1993). The spectrum of bone disease in end-stage renal failure - an evolving disorder. Kidney International, 43: 426-435.

26. Hostetter TH, Troy J C \& Brenner BM (1981). Glomerular hemodynamics in experimental diabetes. Kidney International, 19: 410-415.

27. Zatz R, Dunn BR, Meyer TW, Andersen S, Rennke HG \& Brenner BM (1986). Prevention of diabetic glomerulopathy by pharmacological amelioration of glomerular capillary hypertension. J ournal of Clinical Investigation, 77: 1925-1930.

28. Musso MJ, Barthelmebs $M, I m b s ~ J L$, Plante M, Bollack C \& Helwig JJ (1989). The vasodilator action of parathyroid hormone fragments on isolated perfused rat kidney. Naunyn-Schmiedeberg's Archives of Pharmacology, 340: 246-251.

29. Carney SL \& Gillies HB (1995). Acute ef- fect of parathyroid hormone on urine concentration in the rat. Clinical Science, 88: 197-201.

30. El-Seifi S, Freiberg J M, Kinsella J , Cheng $\mathrm{L} \&$ Sacktor B (1987). $\mathrm{Na}^{+}-\mathrm{H}^{+}$exchange and $\mathrm{Na}^{+}$-dependent transport systems in streptozocin diabetic rat kidneys. American J ournal of Physiology, 252: R40-R47.

31. Harris RC, Brenner BM \& Seifter J L (1986). Sodium-hydrogen exchange and glucose transport in renal microvillus membrane vesicles from rats with diabetes mellitus. J ournal of Clinical Investigation, 77: 724-733.

32. Zaladek Gil F, Costa Silva VL \& Malnic G (1995). Effect of luminal calcium on proximal tubule reabsorption in the rat. Renal Physiology and Biochemistry, 18: 271277.

33. Wongsurawat $\mathrm{N} \&$ Armbrecht HJ (1985). Insulin modulates the stimulation of renal 1,25-dihydroxyvitamin D3 production by parathyroid hormone. Acta Endocrinologica, 109: 243-248.

34. Ng LL, Simmons D, Frighi V, Garrido MC Bomford J \& Hockaday TDR (1990). Leucocyte $\mathrm{Na}^{+} / \mathrm{H}^{+}$antiport activity in Type 1 (insulin-dependent) diabetic patients with nephropathy. Diabetologia, 33: 371-377.

35. Dumlay R \& Hruska K (1990). PTH receptor coupling to phospholipase $\mathrm{C}$ is an alternative pathway of transduction in bone and kidney. American J ournal of Physiology, 27: F223-F231.

36. Demerdash TM, Seyrek N, Smogorzewski M, Marchinowski W, Nasser-M oadeli S \& Massry SG (1996). The pathways through which glucose induces a rise in [Ca]i of PMNLS of rats. Kidney International, 50: 2032-2040.

37. Tanaka H, Smogorzewski $M$, Koss $M$ \& Massry SG (1995). Pathways involved in PTH-induced rise in cytosolic $\mathrm{Ca}^{2+}$ concentration of rat proximal tubule. American J ournal of Physiology, 268: F330F337.

38. Zaladek Gil F, Costa Silva VL, Oshiro MEM \& Ferreira AT (1997). Effects of PTH on intracellular calcium of MDCK cells in culture. Cell Physiology and Biochemistry, 7: 35-42. 